\title{
The political economy of the environmental criminal justice system: a production function approach
}

\author{
Christian Almer • Timo Goeschl
}

Received: 11 March 2009 / Accepted: 25 June 2010 / Published online: 24 July 2010

(C) Springer Science+Business Media, LLC 2010

\begin{abstract}
The criminal justice system combines at least three distinct institutions, police, prosecutors, and courts, in order to enforce key regulations. Focusing on criminal environmental law contained in the German Penal Code, this paper empirically studies the determinants of enforcement decisions at the levels of the police, prosecutors, and judges using a production function approach. We focus particularly on the role of economic and political factors and their comparison across institutions. The results of the panel data analysis show evidence for the presence of economic factors determining behavior at all levels. Political factors impact especially on police and court behavior.
\end{abstract}

Keywords Criminal enforcement · Political economy · Environmental law · GMM

JEL Classification $\mathrm{K} 42 \cdot \mathrm{K} 32 \cdot \mathrm{D} 78 \cdot \mathrm{C} 23$

\section{Introduction}

The criminal justice system ensures compliance with those regulations that the political system deems important enough to apply the most severe forms of sanctions available to society. Its functioning is therefore an essential determinant of policy outcomes (Polinsky and Shavell 2006) and - as a result - has been attracting the attention of public choice scholars at least since Becker and Stigler (1974). Since then, researchers have noted that one of the distinguishing features of the criminal justice system is that it consists of several separate regulatory institutions that are arranged sequentially, rather than a single monolithic system. At the base, there is a police force that monitors and investigates, followed by a prosecution

C. Almer $(\varangle)$

Department of Economics and Oeschger Centre for Climate Change Research, University of Bern, Schanzeneckstrasse 1, 3001 Bern, Switzerland

e-mail: almer@vwi.unibe.ch

T. Goeschl

Department of Economics, University of Heidelberg, Bergheimer Str. 20, 69115 Heidelberg, Germany

e-mail: tg203@uni-hd.de 
service that decides on the basis of police reports and own investigations on the merits of an offence, and, finally, courts that decide on cases brought before their judges by prosecutors. The resulting literature has analyzed these institutions one-by-one, progressively uncovering the political and economic factors that shape the behavior of the police (Mast et al. 2000; Levitt 1997; Benson et al. 1995), prosecutors (Rasmusen et al. 2009; Boylan 2005; Dyke 2007; Baker and Mezzetti 2001; Kobayashi and Lott 1996), and judges and courts (Cohen 1992; Hanssen 2000, 2004a, 2004b; Palmer 1982; Kimenyi and Shughart 1993; Salzberger and Fenn 1999; Ashenfelter et al. 1995; Belova and Gregory 2009). ${ }^{1}$

The objective of this paper is to use a unique dataset that covers the handling of environmental offences in the German criminal justice system in order to examine and compare the economic and political determinants of decisions of police, prosecutors, and courts in a unified perspective rather than individually. Being able to compare determinants across the three different institutions is instructive because it provides empirical evidence on how institutional differences between police, prosecution service, and courts shape their choices about the same subject matter. While the three institutions share a uniform legal background in form of the German Penal Code and a joint overall objective and are procedurally interconnected, police, prosecution service, and courts vary in several important ways. From a public choice perspective, one key dimension is the degree of independence from the political process that these institutions enjoy in Germany: The police force is-as part of the executive branch of government-relatively dependent. Courts, on the other hand, are deliberately set up to operate at arm's length from other branches of government. The prosecution service, finally, combines elements of both dependence and independence: While subject to directions from the executive branch (ministries of justice), prosecutors enjoy considerable autonomy that is safeguarded by law and largely invariant vis-a-vis government. Therefore, agents at different stages of the sequential enforcement process face different incentives and different resource constraints. Comparing these institutions, observed enforcement outcomes at each level should reflect the different degrees of independence. The empirical question is whether this conjecture is borne out by reality. This leads to three sub-questions. The first is what determines enforcement decisions by the police force, prosecutors, and judges within the criminal justice system. The second is whether and if yes, to what degree, decision-makers are responsive to the preferences of voters and politicians. The third is how the influence differs between agents at different stages. Is the conjecture correct that those institutions of enforcement that enjoy greater independence by design are indeed less responsive to the political factors that drive the legislature and executive?

The core of the present paper consists of an empirical approach to answering these questions in a particular context, the enforcement of environmental criminal law. ${ }^{2}$ This highly specific area of criminal law lends itself to an empirical investigation of this type for two reasons. One is that it is an area of criminal law that-because of the complexity of its nature-requires non-trivial amounts of resources to be spent at every level in order to push cases through the enforcement process (Lutterer and Hoch 1997; Cohen 1999). This offers an opportunity to recover from empirical data the economic determinants of enforcement decisions at the level of the police force, prosecution services, and courts because pursuing environmental crimes imposes non-negligible opportunity costs. The other reason is that the environment is a type of public good for which the preferences of the public and politicians are reasonably specific and partially observable: Elections and

\footnotetext{
${ }^{1}$ See Shugart and Tollison (1998) for an additional overview.

${ }^{2}$ See Rousseau (2009) for an overview of related work.
} 
party ideology are just two examples of established proxies for environmental preferences and have been successfully exploited in the past for similar purposes as those of the present paper. Taken together, the workings of the criminal justice system in this particular area should be especially suited for uncovering the resource and political economy factors that shape the system. Methodologically, we take to its logical conclusion the premise common in the public choice literature that the behavior of public agents is the solution to a constraint maximization problem. Conceptualizing their decisions as 'producing enforcement', the paper demonstrates the usefulness of using methods of dynamic production function estimation (Blundell and Bond 2000) for understanding the economic and political determinants of regulatory enforcement.

Our key results are threefold. The first is that decision-makers at all stages of the enforcement process weigh the opportunity costs of their actions. This implies that-very much in line with the economic theory of enforcement and a functionalist view of governmentinstitutions deliberately direct resources away from the enforcement of environmental law as its opportunity cost increases. This responsiveness with respect to costs is evident at all levels, including criminal courts, which enjoy the greatest degree of political independence. It also lends credibility to using a production function approach as a methodological starting point. The second result is that political economy factors influence enforcement at two out of the three stages of the process. This demonstrates that even in the ostensibly most independent parts of the criminal justice system, there is evidence of political reach-through. The third result is that the relative weight of political economy factors is not fully in line with the declared degree of independence: Judges' decisions seem to be as responsive to political economy variables as the police force, while results for prosecutor's decisions are ambiguous.

The paper proceeds as follows: In the following section, we summarize the main features of environmental crime and its prosecution in Germany, emphasizing the three institutions of police, prosecution service, and courts involved in criminal enforcement. We then develop a set of testable hypotheses on the determinants of enforcement decisions at each of the institutions in Sect. 3. Section 4 explains the data sources, followed by a presentation of the empirical strategy and key results in Sect. 5. Section 6 discusses the results and Sect. 7 concludes.

\section{Environmental crime and its prosecution in Germany}

The German Penal Code (Strafgesetzbuch) was extended in 1980 to include environmental offences. The intention behind this move was (i) to raise the level of general deterrence on account of harsher sanctions being available through the criminal justice system, (ii) to harness the additional police, prosecutorial, and judicial resources available in the criminal justice system, and (iii) to improve general awareness of the need for greater environmental protection (Hoch 1994; Schall 2006). Stiffer sanctions were introduced into the German Penal Code in 1994, following the inclusion of environmental protection in the German Constitution as a distinct constitutional objective.

Harnessing the enforcement capabilities of the Penal Code implies the involvement of three distinct institutions in the handling of cases that enter into the criminal enforcement system: These are-in sequence-the police force, the public prosecution service, and the courts. The police forces in the German states, situated at the start of the enforcement sequence, are controlled directly by the executive, being part of the Ministry of the Interior. Operating budgets and personnel resources are largely determined externally. The police 
force's main activity is to respond to the detection of an environmental criminal act by dedicating resources to identifying the probable offender(s). The share of environmental crimes in Germany for which the identity of the probable offender(s) is established, also referred to as the 'clearance rate' of reported environmental crime, is an average of $60 \%$. The contribution of the police force within the enforcement system is therefore primarily the production of so-called 'cleared' cases by identifying probable offenders that are fed into the following prosecutorial stage of enforcement. However, the police force also has to dedicate resources to assist the prosecution service in those cases in which the prosecution service decides to bring a case to trial, raising the cost of investigating new crimes.

At the subsequent stage, the enforcement system involves the public prosecution service. There, prosecutors examine cases with identified suspects and decide on whether to accuse a suspect or not. The prosecution services in the German Lander are part of the respective Ministries of Justice. Prosecutors are appointed, not elected. In common with judges, prosecutors enjoy considerable discretionary power, but are dependent to a significantly greater extent on an executive unit (the Ministry) that determines budget and resources. Like judges, prosecutors operate under the so-called legality principle that requires a prosecution of each and every case that is sufficiently likely to involve a crime. On the other hand, a decision in favor of bringing a case to trial implies that resources need to be dedicated to preparing a case at a level of detail for guilt to be ascertained at the standard required for a criminal conviction. Rational prosecutors will incur the opportunity cost of these resources only if the resultant expected benefits dominate those of other prosecutions foregone. Owing to the technical nature of the subject matter, environmental cases are on average of a relatively high complexity and thus resource-intensive. On average, $25 \%$ of identified offenders are passed on by prosecutors to be tried in court, with the remainder of cases either dismissed for lack of evidence or insufficient severity of the offence or the offender punished using lighter administrative fines that establish no criminal record.

Courts are the third and final distinct institution involved in the criminal enforcement system. The courts consist of judges that enjoy-within the law-full discretionary power on how to sanction. Judges hear cases brought to trial by public prosecutors and decide on whether to convict a defendant, and if yes, what tariff to set as a sanction. Of those defendants ending up in court, more than three quarters (76\%) are sentenced, of which $6.4 \%$ are ordered to pay heavy fines and $3.5 \%$ are sentenced to prison. The rest faces a standard pecuniary tariff.

At each one of the three stages of the enforcement process, institutions involved face opportunity costs in terms of resources and trade-offs in terms of priorities when deciding to what extent to enforce environmental crimes. The subsequent focus in this paper is on the determinants of these enforcement decisions, among them political economy factors that capture policy-specific interests among the population and the ideological orientation of the executive. Given the specific nature of environmental criminal law, observed environmental preferences of the population will be considered as candidate explanatory variables. Likewise, political parties in Germany have a clear profile as to the priority they place on environmental matters (Klingemann et al. 2007). The identity of governing parties will therefore be used to capture these ideological factors that operate either within the executive or are imposed on the executive by virtue of the competitiveness of the political process.

The empirical strategy in this paper is to exploit the devolved nature of enforcement under the German Penal Code. While federal law, its implementation, i.e., detection, prosecution, and sanctioning by courts, is delegated comprehensively to the level of the 16 States (Länder) within the Federal Republic. Unlike in the United States, there is no federal shadow system of federal prosecutors or EPA officers that monitor, assist, remedy, and possibly preempt state-level enforcement. This comprehensive delegation from the federal to the state 
level generates-against a uniform legal background - the natural variation in enforcement choices at the level of police forces, prosecution services, and courts that this paper exploits.

\section{Hypotheses on the determinants of enforcement decisions}

In this section we develop the arguments that give rise to four testable hypotheses regarding the extent to which economic and political factors help explain enforcement decisions of different institutions involved in the compliance assurance process.

\subsection{Police}

As the first of three institutions involved in enforcing the German Penal Code against environmental offenders, decisions of police forces determine the influx of cases into the system by passing 'cleared' cases, that is cases for which suspects are identified, on to the prosecution office. The 'production' of cleared cases is determined by the number of cases on the one hand and the effort dedicated to linking individuals to an illegal act on the other. We proceed in two steps, first focusing on the economic determinants of the production of cleared cases by the police, then discussing the role of political economy factors.

From an economic point of view, the greater production of cleared cases depends on inputs and opportunity costs of effort dedicated to environmental crimes. The number of cleared cases of environmental crime is hypothesized to depend positively on the number of all cases to be investigated. This scale effect hypothesis leads us to predict a positive coefficient. Higher opportunity costs of investigation, on the other hand, shift resources away from investigating environmental crime (Helland 1998). Such opportunity costs are an increased number of overall cases to be investigated, higher production of cleared cases in other areas, and-finally - a larger number of cases of environmental crime proceeding to trial and therefore requiring additional police resources dedicated to preparing evidence to a higher standard of proof. The opposite effect, driven by decreases in opportunity cost, is known to be generated by changes in enforcement priorities towards environmental crime as a result of a growing environmental crime rate. Benson et al. (1995) and Coloninger and Sartorius (1979) identify increases in crime levels as a key driver of inputs available for crime detection and reporting, leading us to predict a positive coefficient. In addition to the scale and opportunity cost effects, there is the question of economies of scope, i.e., the impact of clearing up overall crime on the marginal cost of clearing environmental crimes: Since cases of environmental crime are typically linked to other punishable offences (Hoch 1994), the impact on marginal costs is likely to be negative, implying that a positive economies of scope effect exists.

Turning to political economy considerations, political factors also impact on the opportunity costs of effort. Pro-environmental parties in the administration would be predicted to give higher priority to enforcement resources being shifted towards environmental offences while pro-industry parties would be predicted to have a lower priority. Likewise, an executive administration may want to respond to stronger 'green' sentiment among the population by directing the police force to prioritize environmental offences relative to other areas of crime because the executive shares the population's green preferences or because responding to such sentiment defuses environmental issues as rallying points for competing parties. Given the nature of the police as part of the executive branch, stronger 'green' preferences in the population would therefore be predicted to be associated with a higher volume of cleared cases produced by the police. 
The predictions on how the volume of cleared cases responds to exogenous variables are summarized in the following hypothesis.

Conjecture 1 For reasons of economic constraints, the output of cleared cases of environmental crime by police will (a) increase in the amount of cases to be investigated, (b) increase in the growth rate of environmental crime, and (c) decrease in the number of environmental crime cases tried and in the number of general crime cases to be investigated. The effects of $(d)$ the total volume of cleared cases is ambiguous. For reasons of political economy, the effect of (e) variables capturing 'green' preferences and the effect of a pro-environmental party in government is predicted to be positive, that of $(f)$ a pro-industry party in government to be negative.

\subsection{Prosecutors}

There is a small, but rich literature on prosecutor behavior, starting with Forst and Brosi (1977). Most of these studies focus on the case-specific determinants of prosecutorial activity and productivity within the model of a self-interested prosecutor (Myers and Hagan 1979; Albonetti 1986; Boylan 2005). The empirical results bear out the concept of the prosecutor as a rational decision-maker, balancing expected benefits in the form of successful convictions against opportunity costs of time and resources.

In terms of economic determinants, prosecutors are predicted to respond to more prosecution opportunities in environmental crimes, i.e., cleared cases forwarded by the police, with raising the volume of suspects accused. This is the scale effect of prosecution. As at the level of the police, the scale effect could conceivably be complemented by a scope effect because more environmental crimes are likely to be uncovered as a result of prosecuting other forms of crime. An increase in the number of identified suspects across all areas of crime, on the other hand, will lead to fewer environmental offenders being brought to trial because the opportunity cost of prosecuting environmental offences increases. Since prosecutors cannot be expected to care about deterrence to the same extent as politicians (Miceli 1996), an increase in the growth rate of environmental crime would be predicted to have a smaller effect on the decision on whether to bring case to trial at the margin.

Political economy considerations have only recently been studied in the context of prosecutor behavior. An approach close to ours in spirit is by Rasmusen et al. (2009). Like these authors, we include political economy factors as explanatory variables in the empirical model, predicting that the dependence of prosecutors on the Ministry in terms of resources will make their prosecution decisions responsive to political circumstances such as the identity of the political party in power and the strength of 'green' preferences among the population.

Together, these factors give rise to the following predictions on how the number of cases brought to trial will respond to different variables.

Conjecture 2 The number of offenders of environmental crime brought to trial by public prosecutors will (a) increase in the amount of identified suspects, $(b)$ weakly increase in a growth in environmental crime, and (c) decrease in the number of general suspects to be investigated on account of an opportunity cost effect. The effects of $(d)$ a higher number of overall tried suspects is ambiguous. The effect of (e) political economy variables capturing 'green' preferences and the effect of a pro-environmental party in government is predicted to be positive, that of $(f)$ a pro-industry party in government to be negative. 


\subsection{Courts}

The output of courts in context of environmental enforcement is the production of convicts out of an input of defendants. There is a strong expectation that the decisions of courts should — in the words of Landes and Posner (1975) — be independent of "the sorts of political factors [...] that would influence and in most cases control the decision were it to be made by a legislative body". Empirical tests demonstrate that the record does not unequivocally support the prediction of judicial independence. While some studies find that variables capturing the political environment of current court cases and the judge's own political background do not explain court decisions (Ashenfelter et al. 1995), the balance of the literature tends to emphasize the importance of political economy variables in explaining court behavior (Anderson et al. 1989; Salzberger and Fenn 1999). In other words, the interests of voting public and politicians as well as the ideological convictions of the judges themselves are-more often than not-found to influence judicial decisions at the margin.

The economic factors that are candidates for explaining the behavior of courts in the sample center-again —on inputs and opportunity costs. We predict—on account of a scale effect - that a greater volume of suspects being brought to trial by prosecutors will lead to an increase in the volume of convicts. However, an increase in overall trials will raise the cost of time and effort to argue environmental cases to the required standard of proof. As a result, we predict a negative relationship between the aggregate volume of trials and convictions for environmental crimes. The impact of a growing rate of environmental crime on convictions should be weak, as argued before in the case of prosecutors (Miceli 1996), and if not zero, then positive. The presence of economies of scope between convictions for environmental and other crimes is an empirical question with little prior evidence as guidance.

In the light of the preceding empirical literature on courts, we predict political economy factors to have the same effect as at the previous two levels: A 'greener' population shouldat the margin-lead to more convictions. So should the presence of a green party in government. The presence of a pro-industry party in government, on the other hand, should lead to a decrease in the conviction rate.

Conjecture 3 summarizes these prediction regarding the decision of judges thus:

Conjecture 3 The number of offenders of environmental crimes ending in a conviction by a judge will ( $a$ ) increase in the amount of tried suspects $(b)$ be unaffected by a growth in environmental crime, and $(c)$ decrease in the number of general crime suspects to be tried on account of an opportunity cost effect. The effects of $(d)$ a higher number of convictions for other crimes is ambiguous. The effect of (e) political economy variables capturing 'green' preferences and the effect of a pro-environmental party in government is predicted to be positive, that of $(f)$ a pro-industry party in government to be negative.

The final testable hypothesis concerns the relative strengths of coefficients for variables capturing political economy factors. Different institutions ostensibly enjoy different degrees of independence from the legislature, from the police force with the lowest degree to the courts with the highest degree of autonomy in decision-making. We would therefore expect that the relative responsiveness of these three institutions vis-à-vis the identity of the governing party and the preferences of voters should reflect this. The police force would therefore be predicted to be most responsive, courts the least, and prosecutors somewhere in between. This idea is captured in Conjecture 4.

Conjecture 4 The absolute value of coefficients for political economy variables capturing 'green' preferences and the identity of the party in government should be highest at the level 
of the police, lowest at the level of courts, and between police and courts at the level of the prosecution service.

With our set of four testable hypotheses complete, we now turn to the data used in the econometric specifications.

\section{Data}

Data on crime in Germany are collected at the level of 16 individual states to which enforcement is devolved and at various stages in the state-level enforcement process. Since one state has not released the relevant data, our sample comprises 15 of the 16 states and the years 1995 (1994 in case of reported cases) to 2005 with a small subset of states having incomplete reporting, ${ }^{3}$ leading to an unbalanced panel. Data on reported and cleared cases of environmental and aggregate crime are available from the official police crime statistics (PKS) published by the German Federal Criminal Police Office (BKA). Further necessary data of the sanctioning regime applied to crime, such as the number of trials, convictions and imprisonment, are available from the official prosecution statistics (StVSt) of the Research Data Centre (FDZ) provided by the Federal Statistical Office and its state level counterparts. Data concerning juvenile offenders is included in cleared cases but excluded from the remaining analysis due to the distinct sanctioning regime applicable to this subgroup. However, on average $93 \%$ of all identified suspects for environmental crimes are adults. Data on structural variables that characterize individual states, such as population, size, political, and several socioeconomic variables, are taken from publications of the Federal Statistical Office.

As there is no annual information on environmental awareness available at the state level for the period under consideration, we use two different measures that we think are the best proxies for environmental awareness in Germany. Voting shares and information on the support for the German Green Party at the state level are taken from the Politbarometer survey available at the Central Archive for Empirical Social Research (ZA, Cologne). Specifically, voting shares track the share of people surveyed who would vote for the German green party if there had been elections at the time of the interview. The supporters of the German Green Party indicate the share of respondents that identify themselves as strong supporters of the German Greens (1 on a scale of $1-5$ ).

As an indicator of having a pro-industry government in power, we use the presence of the conservative party (CDU/CSU) in the executive of the state government as a proxy. The CDU (CSU in Bavaria) is the German party that is consistently most closely aligned with business and industry interests and least aligned with environmental policy preferences among the parties in German state parliaments (Klingemann et al. 2007). We also include a dummy for the presence of the German greens in state governments to validate their impact on enforcement. Another important factor determining the success of institutions in enforcing environmental criminal law is the endowment of police, prosecution, and courts with manpower and equipment.

Tables 1 and 2 provide variable definitions and summary statistics for all variables included in the core econometric estimation.

\footnotetext{
${ }^{3}$ No data are available for the state of Saxony-Anhalt. Saarland's date cover 1996-2005, Brandenburg 1995-2005 with the exception of 2002, Hamburg's data 1997-2005. Thuringia's data cover 1998-2005 and Mecklenburg-Vorpommern 2001-2005.
} 
Table 1 Variable definitions

\begin{tabular}{|c|c|}
\hline Variable & Definition \\
\hline cleared env. crimes (cleared) & number of cases for which suspects are identified \\
\hline tried suspects (tried) & number of identified suspects that are accused \\
\hline convicted offenders (convicted) & number of accused suspects that are convicted \\
\hline environmental crime (cases) & reported cases of environmental crime \\
\hline identified suspects (suspects) & number of identified environmental offenders \\
\hline $\begin{array}{l}\text { growth rate of environmental crime } \\
(\Delta \mathrm{CR})\end{array}$ & Growth rate of number of reported cases divided by population \\
\hline aggr. crime cases (agg.cases) & $\begin{array}{l}\text { total amount of reported crimes other than environmental } \\
\text { crimes }\end{array}$ \\
\hline aggr. cleared cases (agg.cleared) & $\begin{array}{l}\text { number of overall cleared cases other than environmental } \\
\text { crime cases }\end{array}$ \\
\hline $\begin{array}{l}\text { aggr. identified suspects } \\
\text { (agg.suspects) }\end{array}$ & $\begin{array}{l}\text { number of identified overall offenders other than environmen- } \\
\text { tal offenders }\end{array}$ \\
\hline aggr. tried offenders (agg.tried) & $\begin{array}{l}\text { total number of accused offender other than environmental of- } \\
\text { fenders }\end{array}$ \\
\hline $\begin{array}{l}\text { aggr. convicted offenders } \\
\text { (agg.conv) }\end{array}$ & $\begin{array}{l}\text { total number of convicted offenders other than environmental } \\
\text { offenders }\end{array}$ \\
\hline dummy conservatives (cons) & indicating whether CDU/CSU is in state government \\
\hline dummy greens (greens) & indicating whether green party is in state government \\
\hline green voters (green.vot) & share of people intending to vote for greens \\
\hline green supporters (green.supp) & share of people indicating strong support for greens \\
\hline
\end{tabular}

Table 2 Summary statistics

\begin{tabular}{|c|c|c|c|c|c|}
\hline Variable & Mean & Std. Dev. & Min. & Max. & $\mathrm{N}$ \\
\hline cleared & 1194.495 & 931.038 & 24 & 4258 & 192 \\
\hline tried & 326.546 & 303.119 & 6 & 1497 & 152 \\
\hline convicted & 249.349 & 236.631 & 4 & 1156 & 152 \\
\hline cases & 1987.62 & 1446.443 & 58 & 5848 & 192 \\
\hline suspects & 1205.708 & 899.89 & 31 & 4211 & 192 \\
\hline$\Delta \mathrm{CR}$ & -0.066 & 0.215 & -0.91 & 0.572 & 192 \\
\hline agg.cases & $40,3910.964$ & $31,4819.94$ & 60,087 & $1,529,653$ & 192 \\
\hline agg.cleared & $20,7172.292$ & $16,1267.241$ & 30,500 & 740,584 & 192 \\
\hline agg.suspects & $99,737.354$ & $77,672.327$ & 17,374 & 344,684 & 192 \\
\hline agg.tried & $77,581.460$ & $65,391.658$ & 10,706 & 253,981 & 150 \\
\hline agg.conv & $63,067.473$ & $52,403.183$ & 8002 & 194,942 & 150 \\
\hline cons & 0.547 & 0.499 & 0 & 1 & 192 \\
\hline greens & 0.182 & 0.387 & 0 & 1 & 192 \\
\hline green.vot & 0.102 & 0.053 & 0 & 0.304 & 192 \\
\hline green.supp & 0.044 & 0.026 & 0 & 0.174 & 192 \\
\hline
\end{tabular}




\section{Econometrics}

In this section we analyze the three successive stages of the enforcement process in Germany empirically. One important issue is whether these different punishment variables are persistent-leading to a dynamic production function (Blundell and Bond 2000)—or not. As we will show in the next few paragraphs there is evidence for persistency in clearing and prosecuting environmental crimes but not at the conviction stage.

The two key challenges implicit in a data set of the present type are potential endogeneity and small sample size. One particular advantage of the production function approach pioneered by Blundell and Bond (2000) is that by building on system GMM as proposed by Arellano and Bover (1995) and Blundell and Bond (1998), ${ }^{4}$ it is able to control for potential endogeneity issues. ${ }^{5}$ The small sample size is handled by employing the common general-to-specific approach: We also included variables indicating the expenditures for police, prosecution and courts as obvious inputs to the enforcement process. However, none of these variables turns out to be significant (see Table 6 provided in Appendix A), leaving us with the specifications presented in Tables 3 to 5 .

When reporting results, we include-in addition to the estimated parameters and the corresponding $p$-values - results for the two key specifications tests proposed by Arellano and Bond (1991). The first one is a test for autocorrelation. The second is the Sargan test of overidentifying restrictions. The Sargan test uses the fact that the system is overidentified and applies those overidentifying restrictions to test for the validity of the instruments. Both tests return $p$-values for rejecting the null hypothesis of zero autocorrelation and of the validity of the overidentifying restrictions. All model specifications are tested using both measures of environmental awareness (green.vot, green.supp) separately as their correlation is relatively high (0.67).

\subsection{Police}

The basis for all later enforcement activities for the major fraction of all reported environmental crimes in Germany ${ }^{6}$ is the initial work of police.

The equation to be estimated for the production of cleared cases is:

$$
\begin{aligned}
\log \text { cleared }_{i t}= & \alpha+\beta_{1} \log \text { cleared }_{i t-1}+\beta_{2} \log \text { cases }_{i t}+\beta_{3} \Delta C R_{i t} \\
& +\beta_{4} \log \text { tried }_{i t}+\beta_{5} \log \text { agg.cases }_{i t}+\beta_{6} \log \text { agg.cleared }_{i t} \\
& +\beta_{7} \text { cons }_{i t}+\beta_{8} \text { greens }_{i t}+\beta_{9} \text { green.vot } / \text { supp }_{i t} \\
& +f_{i}+t_{t}+\epsilon_{i t}
\end{aligned}
$$

where $\alpha, \beta_{1-9}$ are the parameters to be estimated, $f$ and $t$ are state and time dummies indexed by $i$ and $t$, respectively, and $\epsilon$ is the error term.

Table 3 displays the coefficient estimates in the upper part and the results of the specification tests in the lower part. An inspection of the $p$-values shows that the results confirm

\footnotetext{
${ }^{4}$ All GMM estimations have been carried out with the xtdpd command in Stata 11.

${ }^{5}$ As a robustness check we estimated the different specification at the three enforcement stages additionally via bias-correction (Kiviet 1995; Bruno 2005a, 2005b). The results are essentially identical to system GMM estimates and are available from the authors on request.

${ }^{6}$ In $2004,76 \%$ of all cases handled by prosecution were forwarded by police, $20 \%$ were initiated by the prosecution itself and $3.2 \%$ were reported by environmental agencies.
} 
Table 3 Estimation results: police

\begin{tabular}{|c|c|c|c|c|}
\hline & $\begin{array}{l}\text { cleared } \\
\text { (1) }\end{array}$ & $\begin{array}{l}\text { cleared } \\
(2)\end{array}$ & $\begin{array}{l}\text { cleared } \\
\text { (3) }\end{array}$ & $\begin{array}{l}\text { cleared } \\
\text { (4) }\end{array}$ \\
\hline \multirow[t]{2}{*}{ cleared, lag } & 0.676 & 0.589 & 0.691 & 0.677 \\
\hline & $(0.000)$ & $(0.000)$ & $(0.000)$ & $(0.000)$ \\
\hline \multirow[t]{2}{*}{ cases } & 0.225 & 0.292 & 0.187 & 0.196 \\
\hline & $(0.079)$ & $(0.054)$ & $(0.043)$ & $(0.040)$ \\
\hline \multirow[t]{2}{*}{ agg.cases } & -0.416 & -0.494 & -0.406 & -0.403 \\
\hline & $(0.021)$ & $(0.009)$ & $(0.004)$ & $(0.012)$ \\
\hline \multirow[t]{2}{*}{ agg.cleared } & 0.422 & 0.500 & 0.450 & 0.447 \\
\hline & $(0.017)$ & $(0.007)$ & $(0.001)$ & $(0.003)$ \\
\hline \multirow[t]{2}{*}{$\Delta \mathrm{CR}$} & 0.825 & 0.750 & 0.813 & 0.807 \\
\hline & $(0.000)$ & $(0.000)$ & $(0.000)$ & $(0.000)$ \\
\hline \multirow[t]{2}{*}{ tried } & 0.0571 & 0.0758 & 0.0535 & 0.0618 \\
\hline & $(0.230)$ & $(0.155)$ & $(0.177)$ & $(0.177)$ \\
\hline \multirow[t]{2}{*}{ cons } & -0.0468 & -0.0449 & -0.0834 & -0.0812 \\
\hline & $(0.266)$ & $(0.330)$ & $(0.062)$ & $(0.071)$ \\
\hline \multirow[t]{2}{*}{ greens } & 0.0474 & 0.0530 & 0.0156 & 0.0139 \\
\hline & $(0.197)$ & $(0.189)$ & $(0.585)$ & $(0.617)$ \\
\hline \multirow[t]{2}{*}{ green.vot } & -0.253 & & -0.283 & \\
\hline & $(0.321)$ & & $(0.330)$ & \\
\hline \multirow[t]{2}{*}{ green.supp } & & -0.549 & & -0.524 \\
\hline & & $(0.341)$ & & $(0.348)$ \\
\hline $\mathrm{N}$ & 152 & 152 & 152 & 152 \\
\hline Sargan & $(0.764)$ & $(0.702)$ & $(0.159)$ & $(0.136)$ \\
\hline ar1 & $(0.007)$ & $(0.008)$ & $(0.003)$ & $(0.005)$ \\
\hline ar2 & $(0.724)$ & $(0.728)$ & $(0.941)$ & $(0.731)$ \\
\hline
\end{tabular}

Note: time dummies and a constant have been included but omitted here. P-values in parenthesis. All GMM specifications have been estimated with robust standard errors (except for the calculation of the Sargan test). In columns 1 and 2 (3 and 4) 3 (2) lags of the dependent variable serve as instruments for the lagged dependent variable in the differenced equation

the model specification both with respect to autocorrelation and overidentifying restrictions: There is evidence for ar (1) and no evidence for ar (2) for all specifications in Table 3. The Sargan test is not able to reject the validity of the exclusion restrictions at the $10 \%$ level in columns $1-4$.

Columns 1 and 2 display the benchmark results. Columns 3 and 4 help address simultaneity issues between the dependent and explanatory variables: Candidates for simultaneity at this stage are cases, tried, agg.cases, agg.cleared, and $\triangle C R$. To control for this, the model treats the identified variables as being endogenous in columns 3 and 4 .

Comparing the different specifications does not reveal significant differences for most variables: The number of cleared cases (cleared) exhibits moderate time dependency as the lagged variable is highly significant in all specifications. The number of environmental crimes (cases) has a positive and-with elasticities of around 0.19 to 0.30 - significant influence on the production of cleared cases by police. Overall crime cases (agg.cases) 
Table 4 Estimation results: prosecutors

\begin{tabular}{|c|c|c|c|c|}
\hline & $\begin{array}{l}\text { tried } \\
\text { (1) }\end{array}$ & $\begin{array}{l}\text { tried } \\
(2)\end{array}$ & $\begin{array}{l}\text { tried } \\
(3)\end{array}$ & $\begin{array}{l}\text { tried } \\
\text { (4) }\end{array}$ \\
\hline tried, lag & $\begin{array}{l}0.488 \\
(0.000)\end{array}$ & $\begin{array}{l}0.462 \\
(0.000)\end{array}$ & $\begin{array}{l}0.529 \\
(0.000)\end{array}$ & $\begin{array}{l}0.475 \\
(0.000)\end{array}$ \\
\hline suspects & $\begin{array}{l}0.487 \\
(0.001)\end{array}$ & $\begin{array}{l}0.550 \\
(0.000)\end{array}$ & $\begin{array}{l}0.473 \\
(0.001)\end{array}$ & $\begin{array}{l}0.537 \\
(0.000)\end{array}$ \\
\hline$\Delta \mathrm{CR}$, lag & $\begin{array}{l}0.392 \\
(0.000)\end{array}$ & $\begin{array}{l}0.390 \\
(0.001)\end{array}$ & $\begin{array}{l}0.443 \\
(0.000)\end{array}$ & $\begin{array}{l}0.435 \\
(0.000)\end{array}$ \\
\hline agg.suspects & $\begin{array}{l}-0.126 \\
(0.718)\end{array}$ & $\begin{array}{l}-0.419 \\
(0.077)\end{array}$ & $\begin{array}{c}-0.532 \\
(0.077)\end{array}$ & $\begin{array}{l}-0.695 \\
(0.041)\end{array}$ \\
\hline agg.tried & $\begin{array}{l}0.190 \\
(0.483)\end{array}$ & $\begin{array}{l}0.428 \\
(0.021)\end{array}$ & $\begin{array}{l}0.481 \\
(0.083)\end{array}$ & $\begin{array}{l}0.643 \\
(0.043)\end{array}$ \\
\hline greens & $\begin{array}{l}-0.0817 \\
(0.140)\end{array}$ & $\begin{array}{l}-0.0934 \\
(0.006)\end{array}$ & $\begin{array}{l}-0.0649 \\
(0.253)\end{array}$ & $\begin{array}{c}-0.0944 \\
(0.030)\end{array}$ \\
\hline cons & $\begin{array}{l}-0.0564 \\
(0.347)\end{array}$ & $\begin{array}{l}-0.0856 \\
(0.047)\end{array}$ & $\begin{array}{l}-0.0804 \\
(0.234)\end{array}$ & $\begin{array}{l}-0.122 \\
(0.037)\end{array}$ \\
\hline green.vot & $\begin{array}{c}-0.534 \\
(0.770)\end{array}$ & & $\begin{array}{c}-0.333 \\
(0.867)\end{array}$ & \\
\hline green.supp & & $\begin{array}{l}3.399 \\
(0.004)\end{array}$ & & $\begin{array}{l}4.338 \\
(0.000)\end{array}$ \\
\hline $\mathrm{N}$ & 136 & 136 & 136 & 136 \\
\hline Sargan & $(0.234)$ & $(0.301)$ & $(0.229)$ & $(0.357)$ \\
\hline ar1 & $(0.026)$ & $(0.037)$ & $(0.023)$ & $(0.022)$ \\
\hline ar2 & $(0.810)$ & $(0.920)$ & $(0.733)$ & $(0.960)$ \\
\hline
\end{tabular}

Note: time dummies and a constant have been included but omitted here. $P$-values in parenthesis. All GMM specifications have been estimated with robust standard errors except for the calculation of the Sargan test. We again restricted the number of lags to serve as instruments for the lagged dependent variable to 3 (2) in the differenced equation in columns 1 and 2 (3 and 4)

indicate the presence of opportunity costs and overall cases cleared (agg.cleared) point towards a general scope effect. Their parameter estimates are highly significant with elasticities of -0.4 to -0.49 and 0.42 to 0.5 , respectively. Estimates for the growth rate of environmental crime $(\Delta \mathrm{CR})$ are highly significant and positive, with elasticities between 0.75 to 0.83 . This provides clear evidence for the police being responsive to criminal behavior. The amount of suspects brought to court, on the other hand, does not seem to influence the amount of cleared cases, despite its possible resource impacts.

The remaining explanatory variables capture the political hypothesis. There is no evidence that the share of green voters (green.vot), the share of supporters of the greens (green.supp) and the greens dummy (greens) influence police behavior in clearing environmental crimes. However, the dummy for conservatives in government (cons) substantiates a negative and-for the endogenous specifications—-significant connection to cleared cases. 
Table 5 Estimation results: courts

\begin{tabular}{|c|c|c|c|c|c|c|}
\hline & $\begin{array}{l}\text { convicted } \\
\text { (1) }\end{array}$ & $\begin{array}{l}\text { convicted } \\
\text { (2) }\end{array}$ & $\begin{array}{l}\text { convicted } \\
\text { (3) }\end{array}$ & $\begin{array}{l}\text { convicted } \\
\text { (4) }\end{array}$ & $\begin{array}{l}\text { convicted } \\
(5)\end{array}$ & $\begin{array}{l}\text { convicted } \\
\text { (6) }\end{array}$ \\
\hline convicted, lag & $\begin{array}{l}0.0250 \\
(0.580)\end{array}$ & $\begin{array}{l}0.0650 \\
(0.123)\end{array}$ & & & & \\
\hline tried & $\begin{array}{l}0.981 \\
(0.000)\end{array}$ & $\begin{array}{l}0.939 \\
(0.000)\end{array}$ & $\begin{array}{l}1.038 \\
(0.000)\end{array}$ & $\begin{array}{l}0.992 \\
(0.000)\end{array}$ & $\begin{array}{l}0.991 \\
(0.000)\end{array}$ & $\begin{array}{l}0.975 \\
(0.000)\end{array}$ \\
\hline$\Delta \mathrm{CR}$, lag & $\begin{array}{l}-0.0865 \\
(0.270)\end{array}$ & $\begin{array}{l}-0.0582 \\
(0.452)\end{array}$ & $\begin{array}{l}-0.138 \\
(0.181)\end{array}$ & $\begin{array}{l}-0.159 \\
(0.246)\end{array}$ & $\begin{array}{l}-0.149 \\
(0.097)\end{array}$ & $\begin{array}{l}-0.142 \\
(0.168)\end{array}$ \\
\hline agg.tried & $\begin{array}{l}-1.546 \\
(0.011)\end{array}$ & $\begin{array}{l}-1.396 \\
(0.008)\end{array}$ & $\begin{array}{l}-1.754 \\
(0.019)\end{array}$ & $\begin{array}{l}-1.732 \\
(0.013)\end{array}$ & $\begin{array}{l}-2.183 \\
(0.000)\end{array}$ & $\begin{array}{l}-2.150 \\
(0.001)\end{array}$ \\
\hline agg.convicted & $\begin{array}{l}1.521 \\
(0.014)\end{array}$ & $\begin{array}{l}1.371 \\
(0.011)\end{array}$ & $\begin{array}{l}1.582 \\
(0.014)\end{array}$ & $\begin{array}{l}1.628 \\
(0.020)\end{array}$ & $\begin{array}{l}2.164 \\
(0.000)\end{array}$ & $\begin{array}{l}2.140 \\
(0.001)\end{array}$ \\
\hline cons & $\begin{array}{l}-0.0177 \\
(0.660)\end{array}$ & $\begin{array}{l}-0.0194 \\
(0.617)\end{array}$ & $\begin{array}{l}0.0617 \\
(0.300)\end{array}$ & $\begin{array}{l}0.0262 \\
(0.605)\end{array}$ & $\begin{array}{l}-0.0160 \\
(0.688)\end{array}$ & $\begin{array}{l}-0.0239 \\
(0.533)\end{array}$ \\
\hline greens & $\begin{array}{l}-0.0359 \\
(0.436)\end{array}$ & $\begin{array}{l}-0.0338 \\
(0.446)\end{array}$ & $\begin{array}{l}0.0139 \\
(0.789)\end{array}$ & $\begin{array}{l}-0.0111 \\
(0.820)\end{array}$ & $\begin{array}{l}-0.0339 \\
(0.409)\end{array}$ & $\begin{array}{l}-0.0264 \\
(0.582)\end{array}$ \\
\hline green.vot & $\begin{array}{l}0.767 \\
(0.085)\end{array}$ & & $\begin{array}{l}1.970 \\
(0.015)\end{array}$ & & $\begin{array}{l}1.373 \\
(0.004)\end{array}$ & \\
\hline green.supp & & $\begin{array}{l}1.083 \\
(0.153)\end{array}$ & & $\begin{array}{l}0.337 \\
(0.700)\end{array}$ & & $\begin{array}{l}1.420 \\
(0.060)\end{array}$ \\
\hline $\mathrm{N}$ & 136 & 136 & 150 & 150 & 150 & 150 \\
\hline Sargan & $(0.001)$ & $(0.001)$ & & & $(0.128)$ & $(0.356)$ \\
\hline ar1 & $(0.137)$ & $(0.147)$ & & & $(0.129)$ & $(0.160)$ \\
\hline ar2 & $(0.245)$ & $(0.253)$ & & & $(0.237)$ & $(0.261)$ \\
\hline
\end{tabular}

Note: time dummies and a constant have been included but omitted here. $P$-values in parenthesis. All GMM specifications have been estimated with robust standard errors except for the calculation of the Sargan test. In case of System GMM we restricted the lags of the variables serving as instruments to 3 in the differenced equation. For the use of System GMM in context of "static panel" (columns 5 and 6), see Roodman (2006)

\subsection{Prosecution}

It is probably not possible to underrate the role of prosecutors in the context of criminal enforcement. Crucially, their decision not to bring a suspect to trial eliminates all opportunities for a criminal sanction.

With the predictions of Sect. 3.2 in mind, we estimate the following equation:

$$
\begin{aligned}
\log \text { tried }_{i t}= & \alpha+\beta_{1} \log \text { tried }_{i t-1}+\beta_{2} \log \text { suspects }_{i t}+\beta_{3} \Delta \text { CR }_{i t-1} \\
& +\beta_{4} \log \text { agg.suspects }_{i t}+\beta_{5} \log \text { agg.tried }_{i t}+\beta_{6} \text { cons }_{i t} \\
& +\beta_{7} \text { greens }_{i t}+\beta_{8}{\text { green.vot } / \text { supp }_{i t}+f_{i}+t_{t}+\epsilon_{i t}}
\end{aligned}
$$

where-again-Greek letters represent the parameters to be estimated, $f$ and $t$ indicate state and time effects, and $\epsilon$ the error term. In contrast to the previous section, the growth rate for environmental crime is included with one lag. The reason for the different specification 
is that police, at the frontline of enforcement, are likely to learn earlier about the crime rate than prosecutors and judges. ${ }^{7}$ Table 4 presents the estimation results.

Similarly to cleared cases there is evidence that the amount of tried suspects exhibits some degree of persistency. Moreover, both the Sargan test and the autocorrelation tests of order 1 and 2 behave as required. There is therefore no evidence against the estimated specifications.

Columns 1 and 2 display the results for the exogenous treatment of the explanatory variables other than the lagged dependent variable. Columns 3 and 4 again account for potential simultaneity issues. The use of the lagged environmental crime growth rate eliminates simultaneity issues for this variable at this stage. Increases in prosecutions, however, may hinder the clearing of additional environmental crime cases. The reasoning for aggregate identified and tried suspects carries over from the previous stage. We therefore treat suspects, agg.suspects, and agg.tried as being endogenous in columns 3 and 4.

In addition to the evidence in favor of persistency, the amount of identified suspects influences the amount of tried offenders with high significance, with elasticities ranging from 0.47 to 0.55 . As conjectured in Sect. 3.2, the growth of environmental crime is a significant and positive driver of the amount of tried suspects ( 0.39 to 0.44$)$. Estimates for identified and tried suspects have the expected signs and are significant in three out of four specifications with elasticities ranging from -0.42 to -0.7 and 0.42 to 0.64 , respectively. The findings for public environmental preferences are surprising: The share of green voters (green.vot) has a negative, but insignificant effect on the amount of tried environmental offenders. On the other hand, the parameter estimate for share of strong supporters for the German green party (green.supp) has a positive and highly significant influence on the amount of tried offenders. The dummies for presence in government of the German green party and the conservatives return negative signs and are significant for the specification that includes the green.supp variable. Taken together, these estimates do not provide a clear picture regarding the relationship between political variables and prosecutors' decisions.

\subsection{Courts}

As stated in Sect. 3.3, it is plausible to assume that political influence is less significant at the court stage. To test this, we estimate the following estimation equation:

$$
\begin{aligned}
\log _{\text {convicted }_{i t}=} & \alpha+\beta_{1} \log \text { convicted }_{i t-1}+\beta_{2} \log \text { tried }_{i t}+\beta_{3} \Delta C R_{i t-1} \\
& +\beta_{4} \log \text { agg.tried }_{i t}+\beta_{5} \log \text { agg.convicted }_{i t} \\
& +\beta_{6} \text { cons }_{i t}+\beta_{7} \text { greens }_{i t}+\beta_{8}{\text { green.vot } / \text { supp }_{i t}+f_{i}+t_{t}+\epsilon_{i t}}
\end{aligned}
$$

As for prosecutors, the growth rate of environmental crime appears with lag 1 . The remaining variables are analogous to the previous subsections.

The first observation regarding the results in columns 1 and 2 of Table 5 is the absence of persistency in the volume of convictions. For the purpose of comparison, columns 3 and 4 report the estimates derived by using a traditional Fixed Effects model: Except for the environmental awareness measures, the results remain the same. Columns 5 and 6 report the results for system GMM to control for potential simultaneity. In contrast to the previous stages there are fewer sources of potential simultaneity: The number of tried suspects

\footnotetext{
${ }^{7}$ We verified this assumption by including both the current and the lagged variable. The current growth rate had no significant influence in this specification.
} 
for both environmental and aggregate crime is determined by prosecutors' decisions, not by courts. The only possible, although unlikely, simultaneity exists between the amount of convicted environmental offenders and the amount of aggregate convicted offenders as a conviction may imply a longer lawsuit, thus binding additional resources.

A key observation regarding the results is that the input measure for the production of convicted environmental offenders, the amount of tried suspects, has the intended effect at a high level of significance and with an elasticity of around 1 . The estimates for the growth in environmental crimes show a negative sign, but are significant only at the $10 \%$ level for one endogenous specification (column 5) with an elasticity of -0.15 . The variables reflecting the amount of overall tried and convicted offenders also follow the stated conjectures: The number of tried (agg.tried) returns a negative elasticity ranging from -1.4 to -2.2 and the number of convicted (agg.conv) a positive elasticity with values ranging from 1.4 to 2.2. Both elasticities are highly significant throughout all specifications.

The political variables indicating whether the green and/or conservative party are part of the state government do not seem to affect the amount of convicted environmental offenders. The share of green voters (green.vot), on the other hand, points towards a positive influence with an elasticity of around 0.8 to 2 . The estimates for strong green support are positive but not significant for the exogenous specifications. However, treating aggregate convicted offenders as being endogenous leads to a positive and significant estimator with an elasticity of 1.4 .

\section{Discussion}

In this section we contrast previously stated conjectures with our empirical findings. The first conjecture stressed the possible determinants of police clearing behavior regarding environmental crime.

Result 1 We find evidence for (a) the amount of reported cases of environmental crime to increase with the amount of cleared cases. Moreover, there is evidence that (b) the growth rate of environmental crime has the intended shift effects as parameter estimates are positive, significant and robust. There is no support for the hypothesis that the amount of tried environmental offenders decreases the amount of cleared cases (c) through a opportunity cost effect. The effects of aggregate crime variables $(d)$, however, are very definitive. The amount of aggregate crime has a significantly negative effect on the clearing of environmental offenses through an opportunity cost effect. In contrast, the aggregate amount of cleared cases is a positive driver of the amount of cleared environmental crimes. For the political variables there is weak evidence for the conservative dummy to negatively affect police success in clearing environmental crimes. The remaining variables do not influence police behavior.

Our results for the opportunity cost arguments confirm the findings of Helland (1998) in the context of EPA enforcement of pollution control laws. Moreover, we also find evidence for the argument that police may react to changing crime rates as proposed by Miceli (1996). With respect to the political factors, estimates support findings in the existing literature that politicians may have a significant impact on enforcement decisions (Mete 2002; Shipan 2004).

The behavior of prosecution is the next key institution when stepping up the enforcement process. Their key input in the production of tried suspects is identified suspects, resulting 
from the clearing of crime cases. We summarize our empirical findings in the following paragraph.

Result 2 There is clear-cut evidence that the amount of suspects brought to court increases with the number of identified suspects (a). Surprisingly, the growth in environmental crime (b) again has a highly significant and positive effect on the amount of prosecuted suspects. We also find support for our next conjecture (c) that a higher amount of aggregate suspects decreases the amount of tried environmental offenders through an opportunity cost effect. There is also evidence for the scope effect: The amount of aggregate suspects tried increases in the amount of tried environmental offenders. The estimates for the political variables do not show a consistent pattern at the prosecution level.

In contrast to the theoretical considerations by Miceli (1996), we find evidence that prosecutors are responsive to growth in environmental crimes. A higher growth in environmental crimes leads to a significantly higher amount of tried environmental offenders. In contrast to Rasmusen et al. (2009), we find evidence for both political and production-based factors to influence the behavior of prosecutors, but the influence of political variables is not clear-cut.

The final institution involved in the enforcement of crimes are courts represented by judges. Judges finally decide whether to convict a suspect and which kind of sanction to impose.

Result 3 The input of tried offenders has the suggested effect (a) of increasing the number of convicted suspects. There is little evidence that growth in environmental crime has a negative effect on the amount of convicted offenders (b). Similar to previous stages, however, the overall amount of tried suspects has a negative and the overall amount of convicted criminals a positive effect on convicted environmental offender (c) and thus supporting the opportunity cost and scope effect hypothesis. Contrary to initial expectations, we find cautious support for public environmental preferences to positively influence judges' decision to convict offenders $(d)$. Both the share of green supporters and the share of green voters show positive estimates with the share of green voters being significant in all specifications and the strong green support being significant once. The government dummies are not significant in any specification.

Estimates for variables that are part of the production function approach are robust and in line with the findings for police and prosecutors. Moreover, there is again evidence for political considerations to influence judges' decisions as the variables indicating public environmental preferences seem to have a positive influence. This is in line with a literature that demonstrates how political factors have an influence on courts (Anderson et al. 1989; Salzberger and Fenn 1999) or bureaucrats enforcement decisions (Headrick et al. 2002).

Our last conjecture focuses on the degree of political influence at different stages of the enforcement process. Although our empirical findings do show evidence for political economy factors being important determinants of agency behavior, the degree of political influence contradicts initial predictions.

Result 4 Political economy variables seem to influence enforcement of environmental crimes. Especially the dummy for the conservatives meant to reflect a pro-industry policy has a negative and significant impact on police in enforcing the German Environmental Penal Code. Moreover, there seems to be evidence for our environmental awareness measures 
to positively influence the amount of convicted environmental offenders. However, as the degree of control does not decrease at higher levels of the enforcement process, we do not find support for conjecture 4.

\section{Conclusion}

The starting point of this paper was that the criminal justice system combines at least three distinct institutions, police, prosecution services, and courts, in order to enforce key regulations. This proliferation of agencies for a single public task-while grounded in sound constitutional arguments - offers an opportunity for a comparative analysis of the determinants of decisions at the different stages of the criminal justice system. These questions have not been exhaustively examined from an empirical perspective.

The findings of this paper add in a significant way to existing literature. Firstly, we reaffirm the usefulness of the production function approach as a powerful tool for analyzing behavior of law enforcement institutions as pioneered by Becker and Stigler (1974). On its basis, the paper provides new evidence on the role of economic and political factors in explaining the behavior of the criminal justice system. Secondly, it is the first paper to our knowledge to provide this evidence not only at the level of one institution involved in criminal enforcement, but at all three key stages of police, prosecution, and courts. This allows us to compare the empirical record with institutional design choices. These choices would suggest that while the police and - to a lesser extent - the prosecution service can be expected to be responsive to public preferences, the decisions of courts should be independent of political factors. The empirical analysis, on the other hand, finds evidence that both economic and political factors are present at all levels. This means that-faced with scarce resources-police, prosecutors and judges are forced to consider opportunity cost arguments when deciding how much effort to put into enforcement and that political factors influence this decision at the margin. It also means that political economy factors influence agency decision making in significant ways. In line with previous results (Rasmusen et al. 2009), there is evidence that pro-industry parties tend to decrease the enforcement of environmental crimes while public environmental preferences have a positive effect. In addition, there is evidence that police and prosecutors respond to a growth of environmental crime with increased effort in order to provide further deterrence, an empirical finding that contrasts with Miceli (1996).

Acknowledgements The authors gratefully acknowledge financial support of the German Federal Ministry of Education and Research (BMBF) under its WiN research program. We are grateful to John List, the editor, two anonymous referees, and numerous seminar and conference participants at the Universities of Amsterdam, Cambridge, Heidelberg, London, Magdeburg, Montpellier, and Rome for valuable comments on an earlier draft. 


\section{Appendix A}

Table 6 Estimates for different covariates

\begin{tabular}{|c|c|c|c|c|c|}
\hline & $\begin{array}{l}\text { Cleared } \\
\text { (1) }\end{array}$ & & $\begin{array}{l}\text { Tried } \\
\text { (2) }\end{array}$ & & $\begin{array}{l}\text { Convicted } \\
\text { (3) }\end{array}$ \\
\hline \multirow[t]{2}{*}{ cleared, lag } & 0.682 & tried, lag & 0.431 & & \\
\hline & $(0.000)$ & & $(0.000)$ & & \\
\hline \multirow[t]{2}{*}{ cases } & 0.198 & suspects & 0.599 & tried & 1.018 \\
\hline & $(0.072)$ & & $(0.000)$ & & $(0.000)$ \\
\hline \multirow[t]{2}{*}{ agg.cases } & -0.374 & agg.suspects & -0.193 & agg.tried & -1.199 \\
\hline & $(0.053)$ & & $(0.696)$ & & $(0.036)$ \\
\hline \multirow[t]{2}{*}{ agg.cleared } & 0.474 & agg.tried & 0.265 & agg.convicted & 1.276 \\
\hline & $(0.028)$ & & $(0.379)$ & & $(0.027)$ \\
\hline \multirow[t]{2}{*}{$\Delta \mathrm{CR}$} & 0.840 & $\Delta \mathrm{CR}$, lag & 0.375 & $\Delta \mathrm{CR}$, lag & -0.151 \\
\hline & $(0.000)$ & & $(0.000)$ & & $(0.228)$ \\
\hline \multirow[t]{2}{*}{ tried } & 0.0655 & & & & \\
\hline & $(0.146)$ & & & & \\
\hline \multirow[t]{2}{*}{ cons } & -0.0879 & cons & -0.114 & cons & 0.00842 \\
\hline & $(0.077)$ & & $(0.140)$ & & $(0.865)$ \\
\hline \multirow[t]{2}{*}{ greens } & 0.0565 & greens & -0.132 & greens & -0.0250 \\
\hline & $(0.121)$ & & $(0.015)$ & & $(0.624)$ \\
\hline \multirow[t]{2}{*}{ green.vot } & -0.264 & green.vot & -0.996 & green.vot & 2.018 \\
\hline & $(0.257)$ & & (0.639) & & $(0.003)$ \\
\hline \multirow[t]{2}{*}{ spd } & -0.0507 & spd & -0.0616 & spd & -0.0237 \\
\hline & $(0.177)$ & & $(0.475)$ & & $(0.418)$ \\
\hline \multirow[t]{4}{*}{ police } & -0.0993 & & & & \\
\hline & $(0.313)$ & & & & \\
\hline & & enforcement & -0.0418 & enforcement & -0.192 \\
\hline & & & $(0.903)$ & & $(0.475)$ \\
\hline \multirow[t]{2}{*}{ GDP } & -0.0182 & GDP & 0.284 & GDP & 0.754 \\
\hline & $(0.709)$ & & $(0.342)$ & & $(0.144)$ \\
\hline $\mathrm{N}$ & 137 & $\mathrm{~N}$ & 121 & $\mathrm{~N}$ & 135 \\
\hline Sargan & $(0.820)$ & Sargan & $(0.300)$ & & \\
\hline ar1 & $(0.004)$ & ar1 & $(0.028)$ & & \\
\hline ar2 & $(0.472)$ & ar2 & $(0.386)$ & & \\
\hline
\end{tabular}

Note: Estimates in columns (1) and (2) and have been produced applying System GMM. For column 3, traditional FE has been applied. $P$-values in parenthesis. Time dummies (and a constant) have been included but omitted here. 'police' and 'enforcement' indicate the log of real expenditures for police, and for prosecution and courts, respectively. 'GDP' and 'spd' stand for real GDP per capita and the Social Democrats being part of the state government in either state and year 


\section{References}

Albonetti, C. (1986). Criminality, prosecutional screening, and uncertainty: toward a theory of discretionary decision making in felony case processings. Criminology, 24(4), 623-644.

Anderson, G., Shughart, W., \& Tollison, R. (1989). On the incentives of judges to enforce legislative wealth transfers. Journal of Law and Economics, 32(1), 215-228.

Arellano, M., \& Bond, S. (1991). Some tests of specification for panel data: Monte Carlo evidence and an application to employment equations. Review of Economic Studies, 58, 277-297.

Arellano, M., \& Bover, O. (1995). Another look at the instrumental variable estimation of error-components models. Journal of Econometrics, 68, 29-51.

Ashenfelter, O., Eisenberg, T., \& Schwab, S. (1995). Politics and the judiciary: the influence of judicial background on case outcomes. Journal of Legal Studies, 24(2), 257-281.

Baker, S., \& Mezzetti, C. (2001). Prosecutorial resources, plea bargaining, and the decision to go to trial. Journal of Law, Economics, and Organization, 17(1), 149-167.

Becker, G., \& Stigler, G. (1974). Law enforcement, malfeasance, and compensation of enforcers. Journal of Legal Studies, 3(1), 1-18.

Belova, E., \& Gregory, P. (2009). Political economy of crime and punishment under Stalin. Public Choice, $140,463-478$.

Benson, B., Rasmussen, D., \& Sollars, D. (1995). Police bureaucracies, their incentives, and the war on drugs. Public Choice, 83, 21-45.

Blundell, R., \& Bond, S. (1998). Initial conditions and moment restrictions in dynamic panel data models. Journal of Econometrics, 87, 115-143.

Blundell, R., \& Bond, S. R. (2000). Gmm estimation with persistent panel data: an application to production functions. Econometric Reviews, 19(3), 321-340.

Boylan, R. T. (2005). What do prosecutors maximize? Evidence from the careers of U.S. attorneys. American Law and Economics Review, 7(2), 379-402.

Bruno, G. (2005a). Estimation and inference in dynamic unbalanced panel data models with a small number of individuals. CESPRI WP No. 165. Università Bocconi-CESPRI, Milan.

Bruno, G. S. F. (2005b). Approximating the bias of the 1 sdv estimator for dynamic unbalanced panel data models. Economics Letters, 87(3), 361-366.

Cohen, M. A. (1992). The motives of judges: empirical evidence from antitrust sentencing. International Review of Law and Economics, 12(1), 13-30.

Cohen, M. A. (1999). Monitoring and enforcement of environmental policy (pp. 44-106). New horizons in environmental economics. Vanderbilt Center for Environmental Mgmt Studies, Vanderbilt

Coloninger, D. O., \& Sartorius, L. C. (1979). Crime rates, clearance rates and enforcement effort: the case of Houston, Texas. American Journal of Economics and Sociology, 38(4), 389-402.

Dyke, A. (2007). Electoral cycles in the administration of criminal justice. Public Choice, 133(3-4), 417437.

Forst, B., \& Brosi, K. (1977). A theoretical and empirical analysis of the prosecutor. Journal of Legal Studies, $6(1), 177-192$.

Hanssen, F. A. (2000). Independent courts and administrative agencies: an empirical analysis of the states. Journal of Law, Economics, and Organization, 16(2), 534-571.

Hanssen, F. A. (2004a). Is there a politically optimal level of judicial independence? American Economic Review, 94(3), 712-729.

Hanssen, F. A. (2004b). Learning about judicial independence: institutional change in the state courts. Journal of Legal Studies, 33(2), 431-473.

Headrick, B., Serra, G., \& Twombly, J. (2002). Enforcement and oversight: using congressional oversight to shape osha bureaucratic behavior. American Politics Research, 30, 608-628.

Helland, E. (1998). The revealed preferences of state epas: stringency, enforcement, and substitution. Journal of Environmental Economics and Management, 35(3), 242-261.

Hoch, H. (1994). Die Rechtswirklichkeit des Umweltstrafrechts aus der Sicht von Umweltverwaltung und Strafverfolgung. Empirische Untersuchungen zur Implementation strafbewehrter Vorschriften im Bereich des Umweltschutzes. Freiburg i.B.

Kimenyi, M. S., Shughart, W. F. I., \& Tollison, R. D. (1993). What do judges maximize? In: Rowley, C. (ed.) Public choise theory, Elgar reference collection series. International library of critical writings in economics (vol. 24, pp. 139-146). Edward Elgar, Brookfield.

Kiviet, J. F. (1995). On bias, inconsistency, and efficiency of various estimators in dynamic panel data models. Journal of Econometrics, 68(1), 53-78.

Klingemann, H.-D., Volkens, A., Bara, J., Budge, I., \& McDonald, M. (2007). Mapping policy preferences II: estimates for parties, eleetors and governments in central and eastern Europe, European Union and OECD 1990-2003. Oxford University Press, London. 
Kobayashi, B. H., \& Lott, J. R. J. (1996). In defense of criminal defense expenditures and plea bargaining. International Review of Law and Economics, 16(4), 397-416.

Landes, W. M., \& Posner, R. A. (1975). The independent judiciary in an interest-group perspective. Journal of Law and Economics, 18(3), 875-901.

Levitt, S. D. (1997). Using electoral cycles in police hiring to estimate the effect of police on crime. American Economic Review, 87(3), 270-290.

Lutterer, W., \& Hoch, H. (1997). Kriminologische Forschungsberichte. MPI, Freiburg.

Mast, B. D., Benson, B. L., \& Rasmussen, D. W. (2000). Entrepreneurial police and drug enforcement policy. Public Choice, 104(3-4), 285-308.

Mete, M. (2002). Bureaucratic behavior in strategic environments: politicians, taxpayers, and the irs. The Journal of Politics, 64(2), 384-407.

Miceli, T. J. (1996). Criminal sentencing guidelines and judicial discretion. Contemporary Economic Policy, 26(2), 207-215.

Myers, M. A., \& Hagan, J. (1979). Private and public trouble: prosecutors and the allocation of court resources. Social Problems, 26(4), 439-451.

Palmer, J. (1982). An econometric analysis of the U.S. supreme court's certiorari decisions. Public Choice, 39(3), 387-398.

Polinsky, M., \& Shavell, S. (2006). The theory of public enforcement of law. Elsevier, Amstersdam.

Rasmusen, E., Raghav, M., \& Ramseyer, M. (2009). Convictions versus conviction rates: the prosecutor's choice. American Law and Economics Review, 11(1), 47-78.

Roodman, D. (2006). How to do xtabond2: an introduction to difference and system gmm in stata. Institute for International Economics-Center for Global Development Working Paper.

Rousseau, S. (2009). Empirical analysis of sanctions for environmental offenses. International Review of Environmental and Resource Economics, 3(3), 161-194.

Salzberger, E., \& Fenn, P. (1999). Judicial independence: some evidence from the English court of appeal. Journal of Law and Economics, 42(2), 831-847.

Schall, H. (2006). Neue Erkenntnisse zur Realität und Verfolgung der Umweltkriminalität (pp. 395-412).

Shipan, C. R. (2004). Regulatory regimes, agency actions, and the conditional nature of congressional influence. American Political Science Review, 98(3), 467-480.

Shugart, W. F. I., \& Tollison, R. D. (1998). Interest groups and the courts. George Mason Law Review, 6, 953-969. 